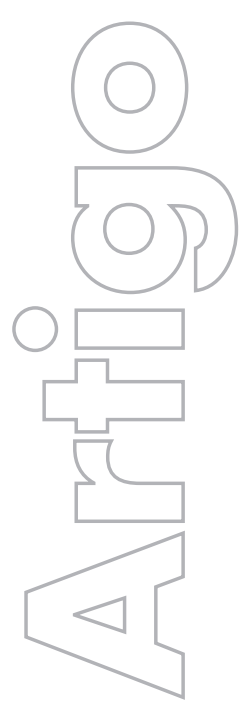

revista

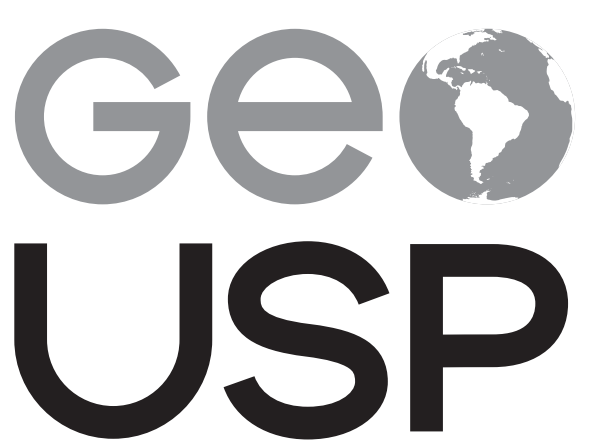

espaço e tempo

Volume $22 \cdot n^{\circ} 2$ (2018)

ISSN 2179-0892

\section{Aquisição e produção do conhecimento em}

geomorfologia: a investigação geomorfológica e seus conceitos fundantes

Pedro Henrique Corrêa de Araújo Barros IGC-UFMG

Roberto Célio Valadão IGC-UFMG

p. $416-436$

Como citar este artigo:

BARROS, P. H. C. A.; VALADÃO. Aquisição e produção do conhecimento em geomorfologia: a investigação geomorfológica e seus conceitos fundantes. Geousp - Espaço e Tempo (Online), v. 22, n. 2, p. 416-436, mês. 2018. ISSN 2179-0892.

Disponível em: https://www.revistas.usp.br/geousp/article/ view/123896. doi: https://doi.org/10.11606/issn.2179-0892. geousp.2018.123896.

\section{(c) (i)}

Este artigo está licenciado sob a Creative Commons Attribution 4.0 License. 


\section{Aquisição e produção do conhecimento em geomorfologia: a investigação geomorfológica e seus conceitos fundantes}

\section{Resumo}

trabalho mostra a Geomorfologia como uma ciência que se estrutura fundamentalmente a partir de dados fornecidos pela observação, findando na construção de leis e teorias de maior escopo, à medida que os fatos se tornam mais refinados devido a aperfeiçoamentos das capacidades de observação e experimentação. Mesmo a natureza da observação sendo ativa e seletiva, já que há "expectativas inatas" que se desdobram em critérios de seleção, culminando, por vezes, em percepções e representações distintas duma mesma realidade, é possível traçar as linhas mestras que balizam e norteiam a estruturação do conhecimento geomorfológico. $\bigcirc$ objetivo do trabalho é, portanto, sublinhar que a produção do conhecimento geomorfológico esteve invariável e historicamente, em menor ou maior medida, atrelada a específicos conceitos fundantes, sistematizados no que se tem, por ora, denominado Tríade Geomorfológica.

Palavras-chave: Tríade Geomorfológica. Ciência geomorfológica. Conceitos fundantes. Teorias geomorfológicas. Epistemologia.

\section{Acquisition and production of knowledge in Geomorphology: geomorphological research and its foundation concepts}

\section{Abstract}

This paper shows that the solidity of scientific knowledge in Geomorphology consists, essentially, from the base provided by observation, resulting in laws and theories of greater scope, as the facts become more refined due to improved capacity of observation and experimentation. However, the very nature of observation is active and selective as there are "innate expectations" that unfold in a selection criteria, which culminates often in different perceptions about the same reality, is possible trace the guidelines that govern the structuring of 
geomorphological knowledge. The object of this work is to evidence that the production of the geomorphologic knowledge has been, invariant and historically, to a greater or lesser degree, associated with specific founding concepts, systematized into what has been called, so far, Geomorphological Triad.

Keywords: Geomorphological Triad. Geomorphological Science. Founding Concepts. Geomorphological Theories. Epistemology.

\section{Introdução}

As formas de relevo, expressão espacial da superfície terrestre, compõem e configuram as mais distintas paisagens morfológicas. Essas, ao florescerem diante dos olhos, despertaram, ao longo da história humana, curiosidade e fascinação. Sendo o relevo terrestre percebido e vivenciado pelos homens, em suas múltiplas escalas, ele assume expressão como recurso ou suporte da vida, "palco do desenvolver da história" nos dizeres de Emmanuel de Martonne (1964).

Indagações diversas acerca da configuração da paisagem alicerçaram mistérios distintivos próprios, que nunca deixaram de excitar uma mistura de emoções em muitas culturas, quiçá na maioria delas, desde a constituição dos pilares da humanidade. Intuitivas classificações, a fim de se cartografarem as formas de relevo e encontrarem respostas para dúvidas sobre a configuração da paisagem terrestre, traduziram diferentes aproximações que "curiosos" experimentaram de uma realidade intrigante. Essas aproximações apenas tangenciavam os limites da paisagem e das morfologias observáveis, sem, contudo, implicar em uma compreensão efetiva da realidade, permanecendo ainda inteligíveis suas (inter)relações processuais (Reynaud, 1971).

Abreu (1982) sinaliza que a sistematização do conhecimento que pode ser considerado verdadeiramente o ponto inicial do processo de edificação de uma ciência que convergiria seus esforços para entender a evolução do modelado terrestre fora iniciada e elaborada durante os séculos XVIII e XIX. Na Europa e nos EUA, surgiram várias e significativas obras que catapultariam definitivamente o saber geomorfológico ao patamar de conhecimento científico, principalmente ao emitir conceitos e teorias que avançaram largamente na busca e no estabelecimento de leis gerais. Materializavam-se ali correntes de pensamento que buscavam encontrar respostas para a origem e a evolução da superfície do planeta de maneiras mais sistematizadas e comprometidas.

Conceitualmente dispersas e variadas, essas obras apontaram uma evolução conceitual aparentemente sem pontos de contato. Entretanto, ao analisá-las mais detidamente, percebe-se claramente que isso não corresponde à realidade, já que é possível mostrar que as mudanças paradigmáticas experimentadas pelo pensamento geomorfológico ao longo do último século são produtos de novas, possíveis a às vezes tão próprias mediações entre certos conceitos quando da apreensão da paisagem pelos geomorfólogos.

Nesse contexto, o objetivo central do trabalho é analisar, a partir das linhas mestras que balizaram e nortearam a estruturação da ciência geomorfológica, como a produção do conhecimento desse moderno campo científico esteve, historicamente, alicerçado na mediação entre específicos e precisos conceitos tão próprios das Geociências, os quais foram sistematizados no que, por ora, se denomina Tríade Geomorfológica. 


\section{Geomorfologia, uma ciência moderna: paradigmas, concepções e seus conceitos fundantes - a tríade geomorfológica}

Ao tratar de aspectos teóricos relativos a um ramo das ciências, faz-se inevitável, num primeiro momento, voltar atenção para a evolução das bases históricas que alicerçaram e delimitaram os objetivos e finalidades deste. Wooldridge (1958) ponderou que o fazer Geomorfologia como campo científico tem, por fundamento primário, considerar e interpretar as distintas morfologias do relevo. Sendo estas "esculpidas pela ação de determinado processo ou grupo de processos, o estudo de ambos pode ser considerado como o objetivo central deste ramo do conhecimento" (Christofoletti, 1980).

Segundo Abreu (1982), a estruturação da Geomorfologia foi inicialmente influenciada pela concepção preconizada pela Ciência da Morfologia de Goethe. Essa se fundamentava sobremodo num método descritivo que exigiria do cientista uma ampla, intensa e contínua atividade de observação e de correlação, quando o pesquisador deveria estar sempre guiado por uma visão do todo. Para tanto, era necessária uma metodologia do olhar para captar as relações na natureza, sendo que o estudo das formas individuais era importante para se compreender o contexto geral (Vitte, 2008).

Todavia, a sistematização do conhecimento que pode ser considerado verdadeiramente o ponto de partida para a análise do processo de edificação da ciência geomorfológica fora iniciado e elaborado durante os séculos XVIII e XIX. Esse início do pensamento geomorfológico mais objetivo, metódico, remete, a princípio, por um lado, às observações que vinculam o trabalho dos rios ao modelado do relevo, o que é muito destacado nas pesquisas dos geólogos americanos do século XIX que exploraram as áreas além Apalaches, notadamente após a conquista do oeste estadunidense. Em contrapartida, na Europa, as abordagens adotam outro sistema de referências, as quais alicerçam-se nas premissas herdadas dos grandes naturalistas, bem como nas observações oriundas de uma análise sistemática da crosta, a partir da interlocução da nascente Geomorfologia com as engenharias de minas, haja vista a emersão das pesquisas vinculadas à prospeç̧ão mineral, quando da busca por matérias-primas para abastecer a industrialização europeia, em consequência da definição dos impérios coloniais (Abreu, 2003).

À medida que o recurso à experiência se tornara definitivamente o meio de teste de afirmações feitas sobre a natureza, ao fornecer manifestas premissas para o estabelecimento de padrões gerais para o comportamento de eventos conhecidos separadamente, um novo mundo alvorecia nos interstícios dos limites do velho. Doravante, o que se viu, conforme aponta Abreu (2003), foi uma evolução da ciência geomorfológica sob dois ${ }^{1}$ sistemas metodológicos e paradigmáticos marcadamente opostos. A corrente anglo-americana - formalização motriz da incipiente ciência (Davis, 1899) - ergueu-se, a priori, sob a égide de posturas mais teorizantes, sem qualquer articulação com uma visão processual mais ampla, culminando numa clara tendência de isolamento e desarticulação da Geomorfologia em relação às demais ciência naturais (Abreu, 1982). Embora o tratamento dado a questões de forma e estrutura envolvidas na produção dos vários estratos do relevo estivessem, à vista do exposto, bem constituídos, acen-

Tanto Abreu (1982) quanto Gregory (1992) apontam, todavia, que outros centros também despontaram como referências na produção geomorfológica. Contudo, na medida em que pouco alteram o dado central das propostas das principais correntes, preferimos omiti-las, já que, por se aproximarem metodológica e filosoficamente das precursoras, a filogênese aqui discutida leva em consideração apenas as precursoras. 
tuavam-se, entretanto, as diversas proposições a respeito da evolução das paisagens baseados sobremaneira numa abordagem eminentemente taxonômica (Chorley, 1978), haja vista que a impressão emanada por volta de 1950 era a de uma Geomorfologia cada vez mais insulada, fazendo seus métodos de análise progressivamente mais obtusos e muito pouco estimulantes. Necessitava a Geomorfologia americana, à luz de alguns autores (Hettner, 1921, 1927; Strahler, 1950a, 1950b, 1952, 1954; Klimaszewski, 1963; Penk, 1953; Chorley; Backinsale; Dunn, 1973), ampliar as relações acerca do como, quanto e do quando das transformações, isto é, embora reconhecendo os avanços e fomentos até então alcançados, as críticas tornar-se-iam mais incisivas e abrangentes ao compreenderem que a práxis geomorfológica erigia-se sobre modelos fundamentalmente teóricos, demasiado valorativos quanto à sequência histórica longínqua, numa franca rescisão e ignorância acerca dos processos operantes, inclusive no estudo de vertentes. Era preciso, pois, remobilizar a ênfase da análise, não só no tocante à escala evolutiva em si, mas e principalmente, acerca de suas associações funcionais, já que essas dependem sobremaneira das investigações dos processos. Por entre avanços, alternativas e objeções, alicerçar-se-iam, posteriormente, seus majoritários esforços em estudos dinâmicos dos processos geomorfológicos e suas relações na gênese global das formas, baseando-se às vezes em métodos de análise quantitativos (Horton, 1945; Strahler, 1950a, 1950b, 1952, 1954; Crickmay, 1959; Hack, 1960; Chorley, 1962).

Diametralmente contrastante, a corrente alemã destacou-se, por seu turno, pela classificação conceitual do objeto da Geomorfologia, isto é, buscava-se uma linha de análise mais global das formas de relevo, integrando-as a uma visão geográfica da paisagem, numa franca concepção integradora dos elementos que compõem a superfície terrestre. Valorizando, desde o início, a observação e a análise dos fenômenos em si, propunha uma perspectiva ambiental empírico-naturalista, de evidente vinculação originária em Humboldt (Moraes, 1989). Também experimentando ampliações, alternativas e adendos, a linha germânica, em seu natural porvir de progresso, não experienciou, entretanto, uma rija ruptura com a tradição de sua práxis em seus aspectos mais fundamentais. Pelo contrário; suas bases já estavam lançadas e muito bem amalgamadas. Por consequência, apesar de os estudos climatogenéticos terem ganhado mais ênfase no último quartel do século passado (Wilhelmy, 1974; Büdel, 1982), num claro esforço de se incorporarem às análises geomorfológicas as condicionantes climáticas quando do estudo do relevo, sua integração teórico-conceitual já era bastante estreita. No limite, fora através da geoecologia e da ordenação ambiental (Kügler, 1976), materializadas no mapeamento geomorfológico, sobretudo no pós-guerra, que as pesquisas teutônicas em Geomorfologia foram assumindo um papel cada vez mais significativo no planejamento regional, estabelecendo e clarificando progressivamente as fronteiras formais da disciplina, ao torná-la nitidamente geográfica.

Nesse sentido, fica evidente que a ciência geomorfológica se apoia e dialoga, historicamente, na interseção de vários outros campos do conhecimento (Selby, 1985). Esses, por sua vez, não existem independentemente um dos outros e os métodos e conceitos motrizes de determinada disciplina são muitas vezes compartilhados entre as demais. $\bigcirc$ progresso e o avanço teórico no estudo geomorfológico representam o quanto a Geomorfologia enriqueceu e se diversificou graças a contribuições coletivas no diálogo com as variadas ciências da Terra (Coltrinari, 2000), pois, mesmo tendo um objeto específico, a ciência geomorfológica não é um campo de pesquisa fechado nele mesmo (Tricart, 1986). 
Muito embora conceitualmente os sistemas apontem, a priori, uma evolução paralela, sem pontos de contato, isso não corresponde à realidade. Mesmo apresentado de forma simplificada, mas tão precisa quanto possível, se reconhece claramente que o desenvolvimento experimentado pela Geomorfologia fora produto de justaposições mútuas entre os conjuntos conceituais aqui supracitados, tendendo-se, consequentemente, às naturais e claras interferências entre ambos os sistemas, cuja aproximação mais evidente se expressa, segundo Abreu (1982), nos estudos de King (1953, 1956, 1967).

Apesar de Abreu (1982) destacar que às vezes é pouco seguro falar em uma teoria para a Geomorfologia como um todo, na medida em que só certos segmentos de seu objeto são passíveis de uma conceituação teórica menos problemática, tem-se, contudo, que a produção do conhecimento esteve, ao longo da história, invariavelmente, em menor ou maior medida, atrelada a alguns conceitos fundantes, sistematizados no que se denomina aqui Tríade Geomorfológica (Figura 1).

\section{Figura 1 - A tríade geomorfológica}

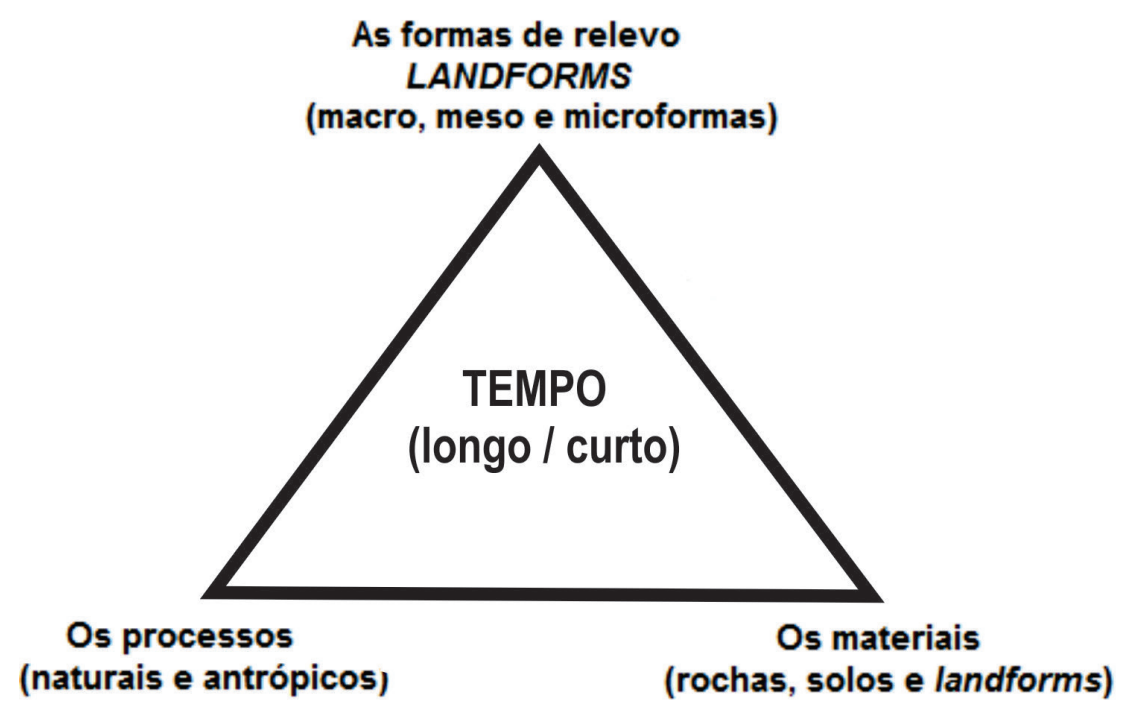

O conhecimento científico em Geomorfologia não se limita ao mero reconhecimento de formas e suas respectivas tipologias. A superfície terrestre, aparentemente monótona e estática, apresenta-se, não obstante, de maneira extremamente dinâmica e multiforme. $\bigcirc$ estudo da morfogênese das paisagens e sua evolução morfodinâmica ao longo do tempo constituem-se como pilares essenciais da ciência geomorfológica. Para tanto, a identificação e análise da atuação dos processos que interferem no modelado dessas formas se apresenta como premissa fundamental no estudo geomorfológico. Os processos que imprimem dinâmica à paisagem atuam sobre materiais, transformando-os e os (re)mobilizando. Na Geomorfologia, os materiais não são outros, senão rochas, solos e as próprias formas de relevo. $\bigcirc$ estudo dos materiais, nos quais ocorrem as transformações do modelado do relevo não pode ser omitido, pois a composição e a estrutura do conteúdo das formas estarão, de maneira ativa ou passiva, participando e interferindo no desenvolvimento e atuação dos processos (Campy; Macaire, 1989). Logo, pela identificação e por interpretações dos indícios e registros dessa ação dos processos sobre os materiais, buscam-se respostas para os diversos efeitos da/na dinâmica evolutiva do relevo, a fim de melhor compreender a estruturação das distintas paisagens morfológicas, ao longo do tempo, em suas mais variadas escalas dimensionais e de complexidade. 
Quando se trata de formas de relevo, devem-se abordar, portanto, invariavelmente, os respectivos processos, agentes e produtos a elas relacionados. Entretanto, a abrangência histórica e dimensional do estudo, bem como a complexidade da análise da realidade que se pretende estudar, estará intrinsecamente correlacionada e será diretamente proporcional à escala espaço-temporal na qual o objeto de análise se enquadra.

Por um longo período da história geomorfológica, o tempo fora assumido, metodologicamente, tal qual é tratado na teoria de Davis (1899), ou seja, como fase evolutiva das formas, subsidiando interpretações do relevo em ciclos, isto é, intervalos de tempo necessários para elaboração de determinados tipos morfológicos (Souza, 2009). Entretanto, ao se considerar a evolução progressiva e, de certa maneira, irreversível2 do relevo, a análise da morfologia torna-se mais temporal do que espacial, já que é em função do tempo decorrido que se deduzem os processos operantes, tendo, pois, apenas no tempo uma base amostral de comparação. Por isso, o tempo, na Tríade Geomorfológica, é entendido como um contínuo de cenários, em um sentido dinâmico, vetorial, jamais cíclico. Produto das considerações de Penck (1953) e legado evidente da análise de sistemas aplicado à Geomorfologia (Strahler, 1950a, 1950b; Hack, 1960; Chorley, 1962), o tempo vai, gradualmente, atenuando suas inflexíveis marcas e a escala temporal, como noção de fluidez, trânsito, tornar-se um elo condutor que sintetiza encadeamentos e sobreposições de processos e que ao longo dela, dinâmicas na transformação do espaço ocorrem (Barros; Valadão, 2016).

No contexto das geociências, ao se explorar a escala temporal, deve-se, obrigatoriamente, periodizá-la conforme a duração dos fenômenos, ou seja, é mister perceber e entender a escala temporal como parâmetro analítico no entendimento dos processos atuantes na transformação da paisagem. Com isso, dois recortes evolutivos, a priori, emergem e se dialogam, sendo um primeiro referente àquele cuja abrangência dos fenômenos/processos é maior, pois se manifestam e são percebidos ao longo do tempo geológico (tempo longo) e um segundo que valoriza as derivações processuais mais imediatas, por vezes antropogênicas, referentes à escala de tempo mais breve (tempo curto).

Mais do que dois recortes evolutivos distintos e aparentemente opostos, estes dois contextos temporais trazem consigo derivações e relações intrínsecas com a escala espacial, quando da apreciação de uma paisagem. Quanto mais se regride na escala temporal, maior será a escala espacial de análise, já que, conforme sinaliza Kohler (2001), a dimensão do evento geomorfológico aumenta com o tempo e, o tempo necessário para o seu desenvolvimento também progride. Assim, no bojo da evolução dos grandes estratos geomorfológicos, há mais variáveis na produção das paisagens, tornando mais morosas as transformações (dinâmicas), e, por consequência, mais latentes os reflexos da atuação dos processos ao longo delas. A escala para abordagem dessas (macro)formas de relevo e dos processos que as originaram e que nelas ocorrem, remete às dimensões, espaciais e temporais, que não são apreendidas pela observação do cotidiano (Roque Ascenção, 2009). Quanto maior a escala espacial adotada, maior também será a influência dos processos endógenos, bem como um aumento da preponderância e notoriedade das morfoestruturas na constituição das formas de relevo.

2 Segundo Chorley (1962), apesar de o ciclo de erosão proposto por Davis (1899) basear-se fundamentalmente em conceitos e dinâmicas próprias de um sistema fechado e, por consequência, uma irreversibilidade, sabe-se, no entanto, à luz do modelo de pediplanação, que um novo movimento crustal pode sim renovar e reverter o estágio do relevo, iniciando um novo sistema fechado. Chorley (1962) denomina tal processo clock back. 
Por outro lado, as microformas, ou seja, aquelas em que a escala de análise às vezes se realiza na evolução de vertentes, têm temporalidades diferentes das que observamos quando tratamos de grandes recortes espaciais. A escala temporal em que atuam e se desdobram os processos, isto é, que trazem consigo feições morfológicas que imprimem e transformam perceptivelmente as encostas, se realizam no tempo curto. Ademais, sendo o homem agente central na produção do espaço geográfico, graças a sua apropriação e modificação da superfície terrestre, o referido recorte temporal, incorpora, necessariamente, as transformações produzidas e consequentes intervenções nos mecanismos morfodinâmicos. A importância desta escala (tempo curto) está justamente por permitir, conforme aponta Hamelin (1964), enfatizar a relevância das análises dessas apropriações espaciais, as quais permitem ver os efeitos mais imediatos dessas ações humanas/sociorreprodutivas.

Destarte, é impossível pensar a escala espacial sem considerar o fator temporal, já que mudanças na paisagem ocorrem obrigatoriamente ao longo do tempo. O modelado de determinada forma e sua abrangência geográfica estão intrinsecamente correlacionados às tipologias de processos atuantes, bem como à duração destes no recorte espacial analisado. Em resumo: a importância e a afinidade entre os conceitos acima relacionados refletem fundamentalmente nos métodos e fazeres geomorfológicos. Ao se debruçarem sobre as macroformas do relevo, os geomorfólogos dialogam, obrigatoriamente, numa perspectiva de tempo profundo, longo. Por conseguinte, os processos que explicarão essa dinâmica e estruturação macro serão os naturais, jamais os antrópicos. Em contraste, os estudos que se desdobram sobre o entendimento das ações antropogênicas no relevo delimitam, mesmo que subjetivamente, uma escala temporal e espacial determinada: o tempo histórico/humano. Logo, é a escala de análise do estudo que irá determinar as estratégias, métodos e técnicas de abordagem da análise geomorfológica. Cria-se, por conseguinte, um forte e estreito diálogo entre a escala temporal e a escala espacial; uma relação simbiótica.

Mesmo que exposto de maneira preliminar, mas tão preciso quanto possível, depreende-se que a edificação da Geomorfologia, numa era polimática, estabeleceu um campo científico que homologou, de certa forma, balizas precisas e, ao mesmo tempo, gerais a conhecimentos que estavam, até então, heterogeneamente dissolvidos e dispersamente incorporados a múltiplos campos do saber. Mais especificamente, a ciência geomorfológica experimentava e estabelecia, assim, para si, propósitos comuns quando de sua iniciação científica, lançando bases concretas, em consequência dum pensamento salutarmente estruturado, na busca explicativa do desenvolvimento das formas de relevo, alicerçado em relações causais dos fenômenos naturais. Ao propor, de maneira sistemática e ordinal, uma abordagem estruturalmente explicativa da morfologia do relevo, a partir duma terminologia concernente, propiciava à atividade cientifica em Geomorfologia condições de desenvolvimento e sustentação própria.

Por conseguinte, se numa primeira análise o que se apreende é uma diversidade de posturas caleidoscopicamente embaralhadas, depreende-se, no entanto, numa reflexão histórica posterior, uma unidade conceitual. Produto de um esforço coletivo e histórico, nem sempre com proposições de ideias imediatas, tampouco sequenciais, a Geomorfologia fora desenvolvendo uma trama categorial que a possibilitava não somente abordar e classificar o relevo com retidão, mas favorecia, também o manifesto reforço do seu próprio campo científico, em conformidade com seus níveis de tratamento e de seus métodos de investigação. 


\section{Verdade das percepções e a relatividade dos enunciados: a abordagem geomorfológica}

As várias morfologias do relevo refletem, indubitavelmente, um conjunto de processos dinâmicos vigentes durante sua formação, muito embora elas estejam sendo continuamente reafeiçoadas e esculturadas. As formas e seus materiais correlativos (Penk, 1953) testemunhariam, portanto, a sucessão de eventos, processos e ainda quadros paleogeográficos, por meio de determinados signos e vestígios, que as condições ambientais variaram consideravelmente no tempo, seja nos mecanismos, suas intensidades e magnitudes, em decorrência da alternância e mudança nos ritmos tectônicos, climáticos e eustáticos de um determinado contexto geomorfológico (Klein, 1960; Dott, 1983). O relevo resulta, destarte, de situações de equilíbrio dinâmico (Hack, 1960) ou ainda, de "desequilibrios sustentados" (Saadi, 1998), produto das diferenças na taxa de atividade endogenética/exogenética, consoante a suas variações cambiantes no tempo e no espaço (Morisawa, 1975) fazendo com que a sua compreensão se realize pela consideração entre os conceitos da Tríade Geomorfológica em todas suas ordens de grandeza e reciprocidade (Figura 2).

\section{Figura 2 - Inter-relações entre os conceitos da Tríade Geomorfológica e as dinâmicas escalares do fenômeno}

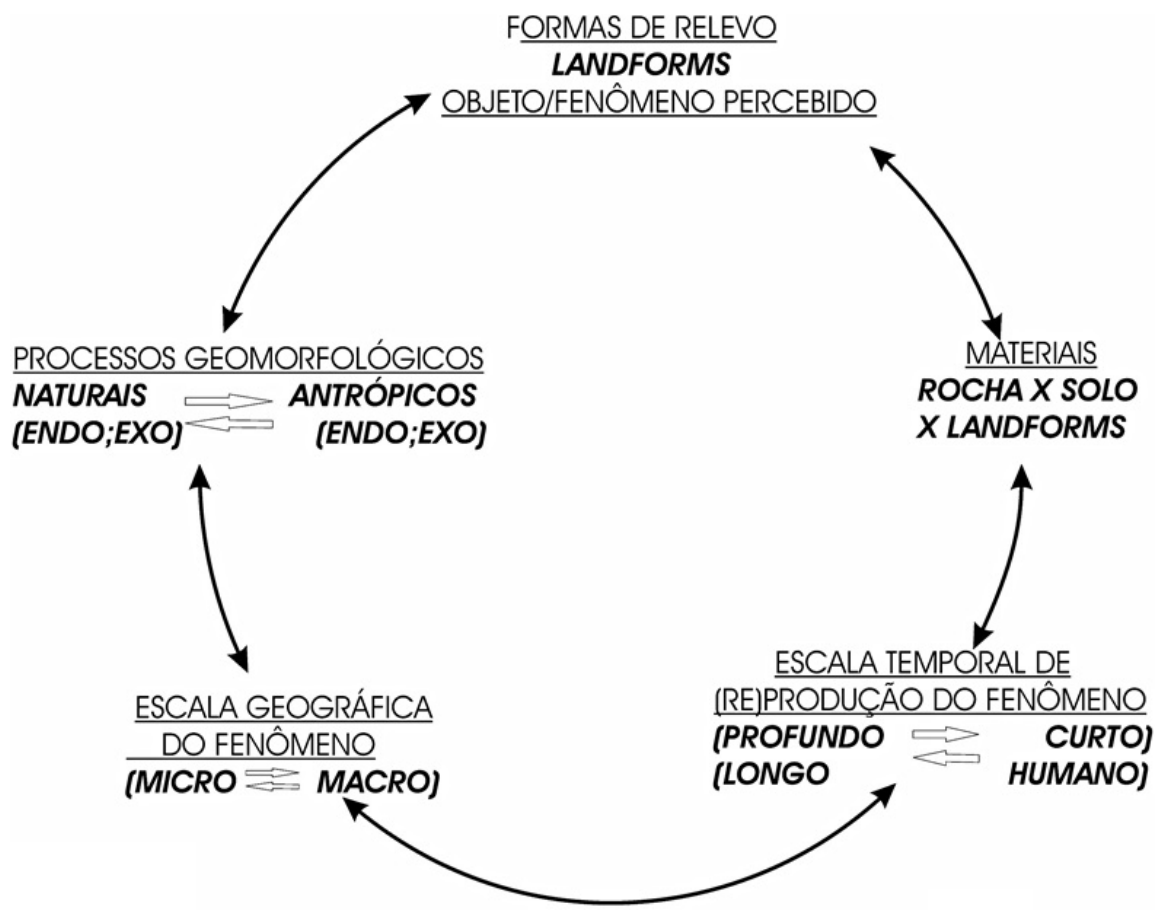

Formas, contornos, volumes. É, pois, pela apreciação direta da fisionomia das paisagens, em sua mais ordinária, evidente e tátil concretude, que alvorecem os critérios iniciais na consideração dos elementos do relevo, a partir duma razão ordenatória, fundamentalmente estética. Contato direto com o objeto de estudo pelo desenvolvimento de uma capacidade aguda de observação, parte-se, assim, essencialmente da materialidade do mundo das formas. Reconhece, dentro do todo, aquilo que se pretende investigar. Identifica, distingue, seleciona. Concede à produção científica em Geomorfologia fundamento, amparo. Nas palavras de Ritter (1986, p. 3): 
[...] the real test of geomorphic validity is outdoors, where all the evidence must be pieced together into a lucid picture showing why landforms are the way we find them and why they are located where they are. A prime requisite for a geomorphologist is to be a careful observer of relevant field relationships.

Estratégia inaugural de descoberta, a pronta percepção das formas em suas naturais distinções morfológicas concede à observação o instrumento investigativo primeiro do geomorfólogo. Valorativa por excelência (Popper, 1975), essa apreensão assenta-se diretamente no real, naquilo singularmente examinado, particularmente verificado. As asserções que alvorecem da atividade observacional são tidas como verossímeis, pois os pressupostos de sua estruturação podem ser verificados intersubjetivamente por todos, sem recurso algum de qualquer tecitura teórica.

Mas não basta contemplar. Detectar as formas dispostas no espaço, apesar de exprimir uma primeira aproximação, deixam obscurecidos, ainda da compreensão, dimensões outras acerca das condições, processos e dinâmicas que promovem a gênese e organização das diversas morfologias as quais a percepção mais explíita abarca. Esse imediato, apesar de ser sim uma progressão no itinerário do saber - pois através dele se constata que algo existe - sua mera forma, ainda que também seja o ente, o é, todavia, uma fugaz manifestação; contingente, temporária. Há uma coisa, por detrás desse imediato, que ao mesmo tempo se dissimula e se expressa nele; e nós atingiremos "algo" mais real: o próprio ser, sua "essência" (Lefebvre, 1991, p. 216).

Com o ordenamento dos fatos geomorfológicos em uma taxonomia hierarquizada (Birot, 1955; Cailleux; Tricart, 1956; Tricart, 1965; Ab'Saber, 1969), os espaços do ecúmeno vão sendo paulatinamente sistematizados e a crosta terrestre, como conjunto de unidade de relevos, tornase, então, produto de uma regular e estrita relação causal - os sistemas morfogenéticos (Cotton, 1958). Baseando-se, pois, na recorrente reiteração de eventos e seus produtos, os quais ocorrem, majoritariamente, sob as mesmas condições (Wolman; Miller, 1960), e vale esse destaque - partem, predominantemente, de semelhantes condições iniciais e findam em equivalentes conjunturas, tendo, por certo, análogas circunstâncias de alteração - coligiu-se, então, empiricamente, a expectar, com o máximo grau de segurança, a repetição da mesma mutação e considerar, assim, o já sabido como ensaio e orientação em relação ao desconhecido (Hume, 1989). Mais especificamente, servindo-se majoritariamente de sofisticadas técnicas classificatórias e estatísticas, busca-se então experimentalmente, na quantidade suficiente e necessária, ${ }^{3}$ distinguir o que é verdadeiramente essencial daquilo que é acidental no contexto que se pretende estudar. Reconhecendo os idênticos e apartando as recorrências anômalas, descartar-se, então, a possibilidade

3 Se numa ampla variedade de condições observa-se uma grande quantidade de "A" e se todos os "A" observados apresentarem, sem exceção, uma propriedade "B", então todos os "A" têm a propriedade "B". Todavia, para os críticos, o método de pesquisa indutivista sofre de graves deficiências, que se originam da vagueza e ambiguidade da exigência de que um "grande número" de observações deve ser feito sob uma "ampla variedade" de circunstâncias pelas quais o observador deve operar sua aproximação (Chalmers, 1993). Por um lado, a indução, cuja pretensão repousa na validade de uma proposição geral elaborada a partir de alguns casos particulares, pode ter um ambiente amostral insuficiente e/ ou tendencioso, traduzindo-se em derivações gerais errôneas ou, no mínimo, pouco condizentes com a realidade. Em contraste, uma indução, cuja proposição geral deriva da observação de todos os casos particulares, se apresenta como tarefa reconhecidamente impossível, devido à puerilidade da vivência humana. Criam-se, portanto, cenários impróprios e incertos que asseguram o soerguimento de afirmações e verdades gerais, a partir deles. Ora tem-se a brevidade do ser humano, impossibilitando que se se debruce sobre todos os fenômenos que se busca investigar (indução completa) e com isso induzir verdades absolutas; em contrapartida, a enumeração de casos particulares culmina fatalmente numa indução cuja verdade é inferida probabilisticamente (indução incompleta). Stuart Mill (1989, p. 166) vê o método de indução como "um procedimento por inferência; [que] vai do conhecido para o desconhecido [...]". 
das variações circunstancialmente provocadas, para que somente daí se possa legitimamente afirmar ou negar algo. Encerrando, por conseguinte, informações sobre realidades ou fenômenos outrora particularmente observados - inclusive, novos são, também, absorvidos e ajudam na reinterpretação dos antigos - rastreiam-se condições constantes e análogas entre as partes a fim de descortinar, enfim, afirmações acerca de suas relações essenciais e contumazes.

Assim, o percurso científico vai-se complementando por meio dum itinerário analítico, num franco caráter de catalogação, o qual, partindo de dados particulares, suficientemente constatados, possibilitam o estabelecimento de regularidades gerais/universais, por vezes, não evidentes naquelas partes então examinadas. Inferidas, aquelas podem (e devem) gerar consequências, não só explicativas, mas sobretudo preditivas - as teorias (Figura 3).

\section{Figura 3 - Percurso metodológico inaugural em Geomorfologia, balizado por claros contornos do indutivismo.}

Produto de uma síntese factual, por meio de uma interpretação especulativa, chega-se a uma conclusão que é sempre provisória (Popper, 1975), já que novos fatos levam a sua reinterpretação.

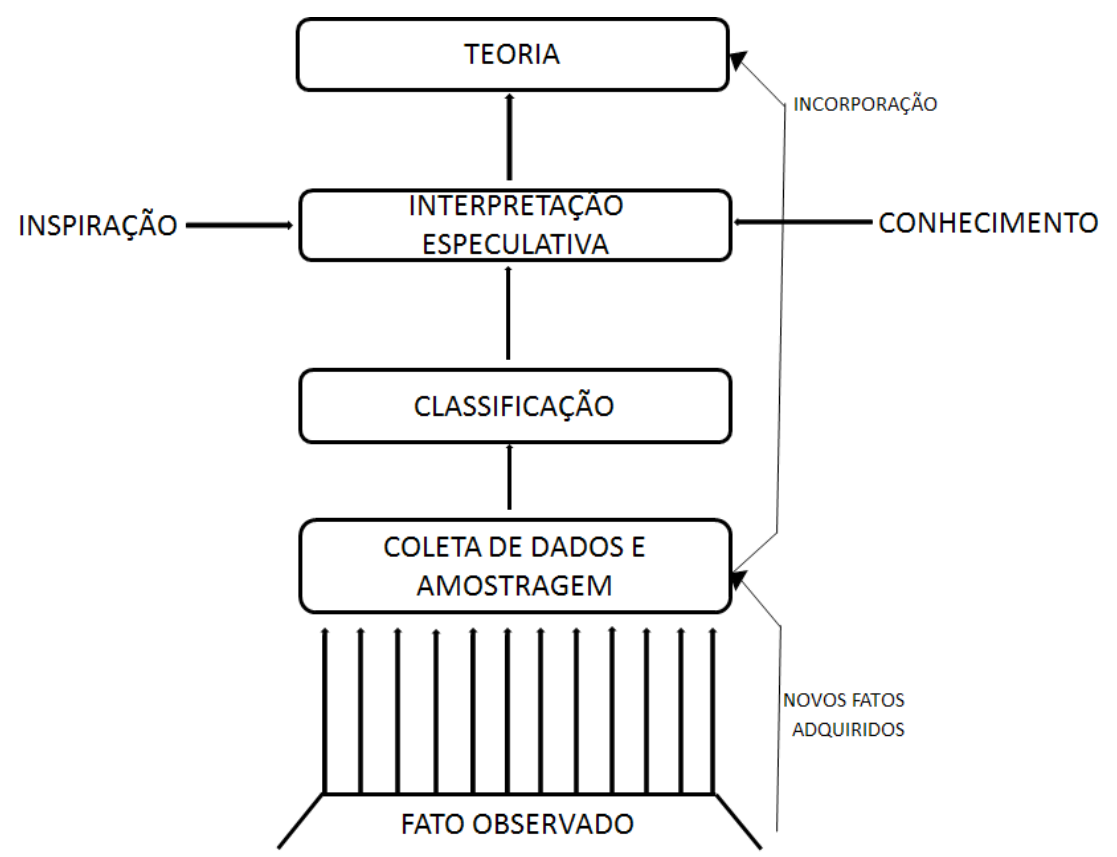

fonte: Adaptado de Moss (1977).

Apesar de equivaler-se largamente a sua gênese - no corolário da ciência moderna acerca da valorização dum empirismo meticuloso e da apreciação imediata como chancela falsificacionista das asserções propostas (Popper, 1975), devido à frequente inacessibilidade e sucessão espaço-temporal dos ambientes/eventos promovedores das mudanças do/no relevo (Bryan, 1941), ou ainda, pela dificuldade da medição direta dos processos geomórficos, por vezes de ocorrência rápida, imprevisível, inclusive, ocasionalmente perigosa (Rhoads; Thorn, 1993), é mister em se considerar, quando da investigação geomorfológica, a conformidade da escala do fenômeno em si investigado. Frequentemente mais intricada e dilatada do que a imediata e manifesta concretude do registro, haja vista o encadeamento processual e a incerta preservação de seus produtos correlativos ao longo do fluxo temporal, a abordagem geo- 
morfológica compele aquele que estuda o relevo a pôr-se além duma aproximação puramente métrica, física, empírica e a periodizá-la também por seus atributos qualitativos - estrutura, dinâmica, fisionomia - subsidiados pela visão sistêmica (Harrison, 2001), aportando, pois, na escala geomorfológica dos fenômenos (Souza, 2009).

Assim, particularidades outrora escrutinadas vão gradualmente se qualificando. Ordena, agrupa, combina. A realidade converte-se em informação, elemento abstrato de uma ocorrência concreta, que vai fundamentando a produção do conhecimento. $\bigcirc$ heterogêneo torna-se, enfim, comparável. De suas relações, postas na forma de argumentos lógicos, sustenta e nutre ideias, as quais, quando referenciadas a cenários de recorrência causais e regularidade contumazes (Hume, 1989), são oportunamente expandidas, generalizadas. Pouco a pouco, aquela ciência instintivamente empírica problematiza o mundo, portanto, também, a partir de generalizações aceitas, de teorias abrangentes, para casos concretos, porções de classe de fenômenos que já subjaziam àquelas, numa conexão descendente (Figura, 4). Em resumo, a pesquisa geomorfológica parte legitimamente da abstração teórica para a concretude dos fenômenos particulares, buscando, quando necessário, pelo experimento, submeter a informação/ conhecimento/dado a um circuito metodológico de permanente depuração dos erros.

\section{Figura 4 - Estrutura de um raciocínio na pesquisa geomorfológica.}

Ambivalente, o sistema permite um movimento duplo, partindo tanto de asserções gerais em níveis descentes de complexidade (dedução) quanto num movimento ascendente, indo do contingente (fenômeno) ao abstrato (raciocínio) - indução

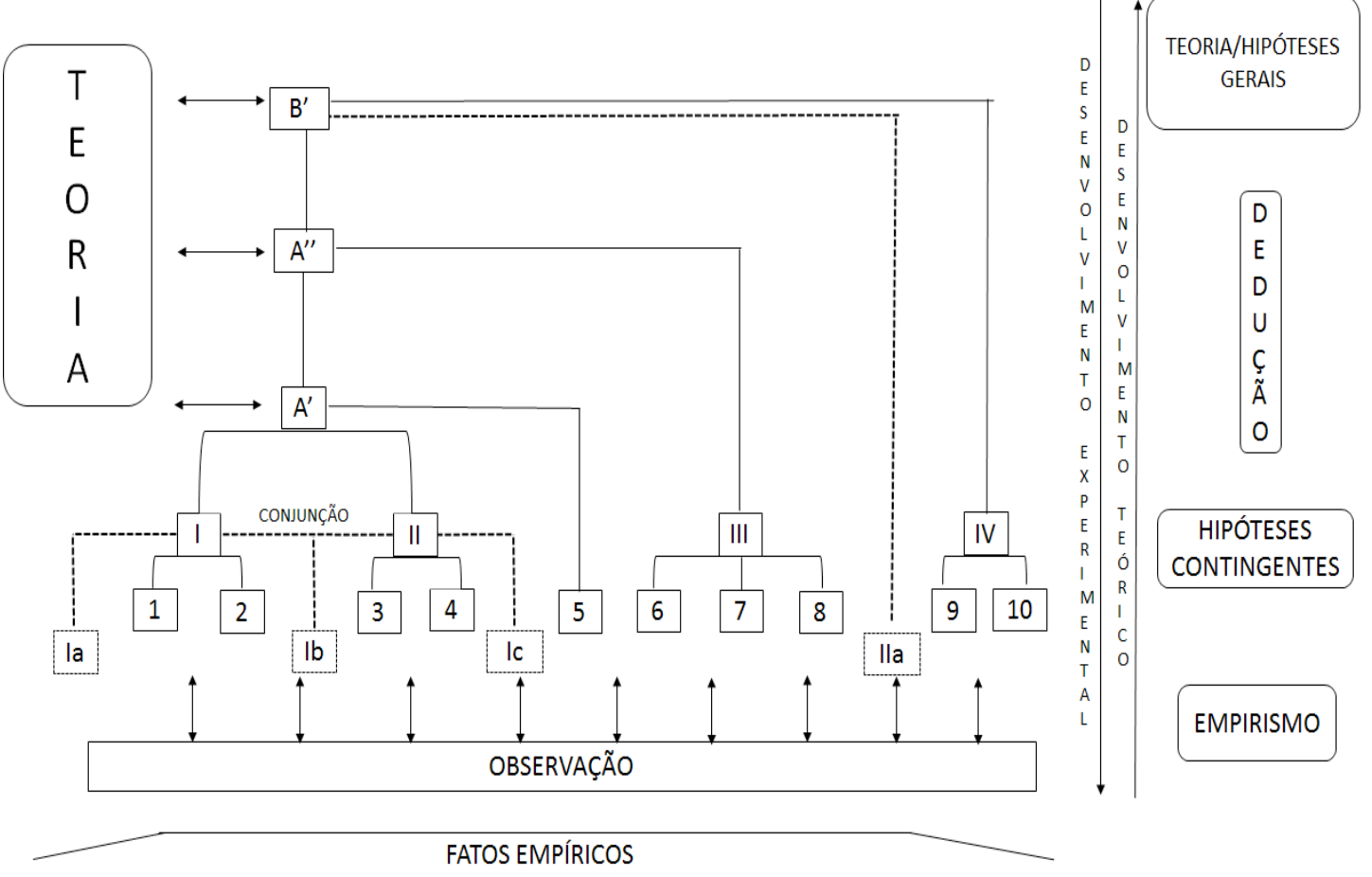

fonte: Adaptado de Moss (1977).

Ainda que a Geomorfologia padeça, em termos kuhnianos, de traços duma típica ciência imatura (Kuhn, 1978), haja vista a falta de uma unidade em seu programa de pesquisa, afinal, seu percurso metodológico não passaria de uma interminável "remendada tecitura de ensaio-e-erro" (Lakatos, 1979), refém, pois, de um método de múltiplas teorias (Chamberlin, 1987), elas, no 
entanto, ao revelarem-se, inegavelmente, capazes de apreender, justificar e prever a riqueza das mutações espaciais verificadas no âmbito dos sistemas de produção das morfologias terrestres, asseguram, por consequência, uma genuína, precisa e fértil ferramenta metodológica à disciplina. Logo, o campo geomorfológico passou a não ser exclusivamente dependente da empiria, isto é, sua existência requerer, também, um arcabouço teórico-conceitual, cujo alvorecer conferiu ao corpus da disciplina mais do que forma e balizas, mas sim, crítica e abrangência.

Nesse sentido, similarmente àquele prevalecente e tradicional padrão teórico e metodológico da pesquisa geomorfológica, baseado fundamentalmente num "descritivismo observacional e em mapeamentos pontilhistas" (Menegat; Fernandes, 1994, p. 179), novos e possíveis pressupostos racionais e seus desdobramentos lógicos permitem, a partir da identificação de problemas (lacunas) existentes entre expectativas teóricas e as efetivas ocorrências em campo, conduzir uma análise seguramente científica. Destarte, é inegável que a concretização da pesquisa geomorfológica progrida, pois, por meio da observação objetiva para formular leis e teorias; mas seus resultados vão sendo avaliados e alcançados, igualmente, para além de aspectos eminentemente concretos, ou seja, por ações teóricas que apontam, por caminhos lógicos, soluções outras, mesmo que ao final essas sejam compulsoriamente verificadas (Popper, 1975 , 1982), a fim de porventura iluminar suas fraquezas (Figura 5).

\section{Figura 5 - Estrutura dum programa de pesquisa em Geomorfologia.}

Partindo de um arranjo teórico, surge indícios acerca da ordenação de uma realidade. Estabelecido na forma de um modelo-umaideia formalmente estruturada-, é testado contra apropriadas derivações lógicas, inclusive numa experimentação crítica, afim de eventualmente falsear o referido pressuposto teórico. Se falseado, as premissas que o sustentam podem ser reexaminadas. Se refutadas, são temporalmente descartadas; do contrário, são reincorporadas ao escopo teórico da disciplina. Destaca-se que as realidades objetivamente apreendidas servem tanto para pôr à prova os preceitos teóricos quanto e inclusive para estruturar novas teorias

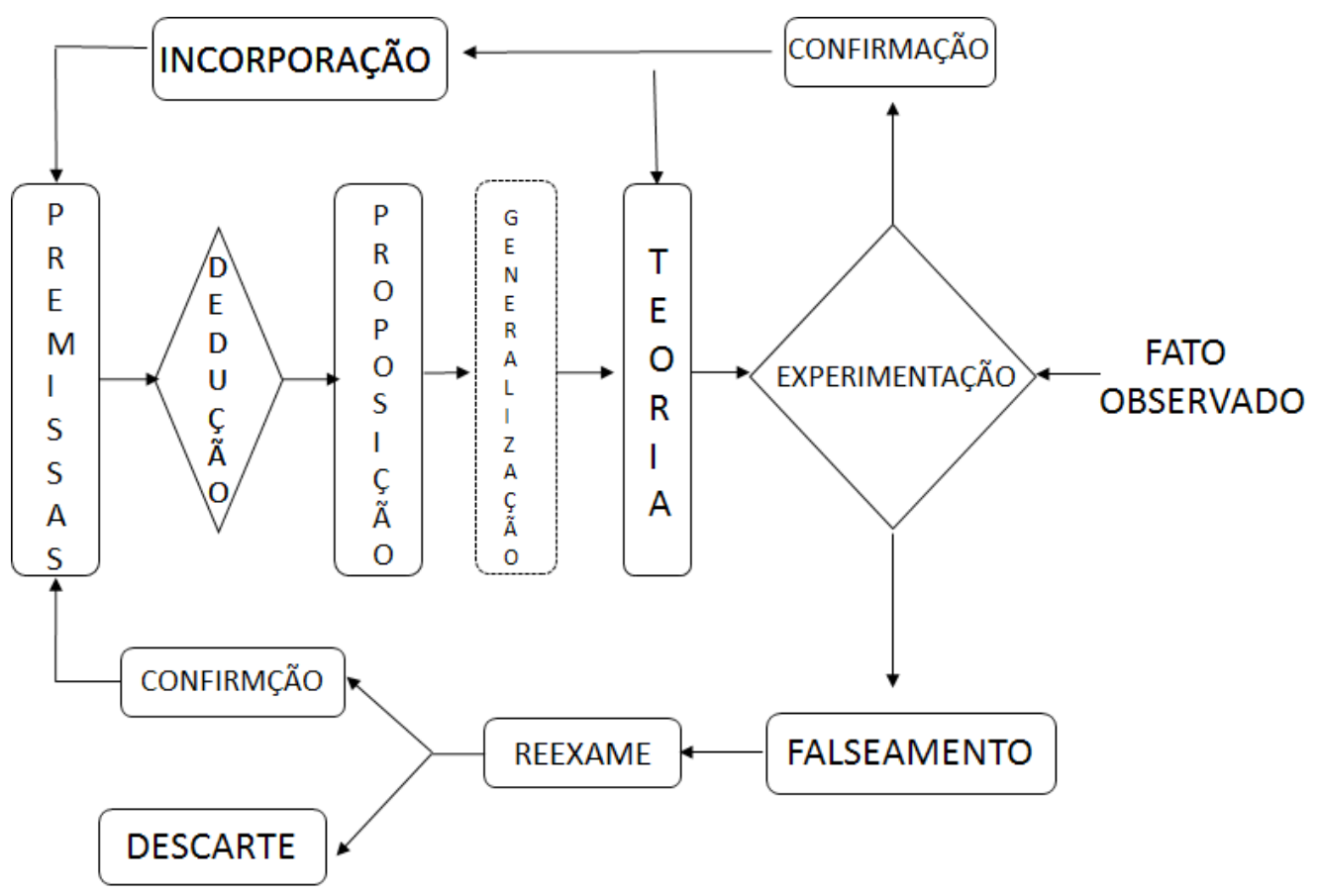

fonte: Adaptado de Moss (1977). 
Pautando numa/duma dualidade existencial, já que o conhecimento se erige em razão do contato confluente entre o sujeito cognoscente e o objeto a ser conhecido, a abordagem geomorfológica, apesar de iniciar-se sim mormente por via experimental, se alicerça também, a partir e em convergência com a consideração especulativa, teórica sobre a escala geomorfológica dos fenômenos à luz de suas inter-relações (Figura 6), pois é só munido de uma teoria do objeto que se consegue adequar o especifico registro geomorfológico outrora apreendido dentro de uma dinâmica sistêmica mais abrangente e assim definir a totalidade na qual ele pode ser explicado (Jolivet, 1969).

Figura 6 - As várias possibilidades de relação e abordagem sujeito X objeto na produção do conhecimento geomorfológico

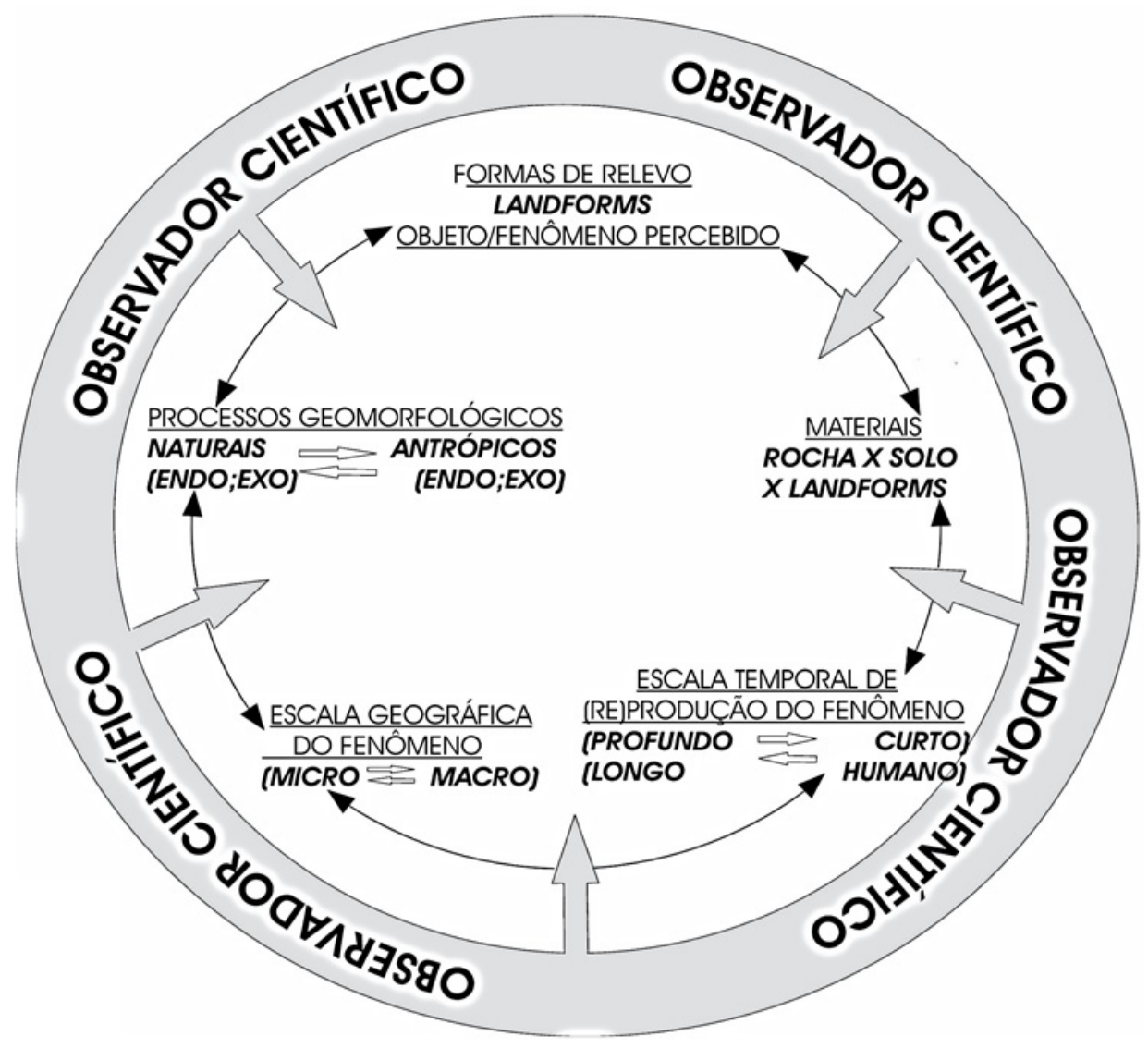

O pretendido ponto final desse roteiro de pesquisa é, senão, a materialização desse saber. Consubstanciando-se no texto, num registro gráfico, tão preciso em seu hermetismo sintático quanto possível, a atividade científica reclama por uma conclusão. Na Geomorfologia, por sua informação encerrar necessariamente referências e relações espaciais, sua culminância jaz, mais especificamente, quando em vez, sobre a arte dum mapa. Ilustra, precisa, espacializa. Tal como qualquer outro meio de comunicação, ele também tem suas regras e exige um mínimo de conhecimento por parte daqueles que o utilizam. Traduzindo espacialmente aquela informação outrora dispersa, dá-lhe chão, referência, azimute. A expressão cartográfica alvorece como relevante ferramenta de representação da síntese espacial e se (re)afirma, também, como importante linguagem do geomorfólogo. 
Entretanto, a interpretação da configuração de determinada paisagem em seus múltiplos aspectos dinâmicos e evolutivos, apresenta-se, por vezes, bastante controvertida e embaraçada ao longo da literatura. Isso porque grandes desafios se apresentam e são postos ao olhar do pesquisador, uma vez que identificar, no estado atual da arte, na maioria das vezes precário (Saadi, 1998), o limiar das verdadeiras influências dos processos nas formas não se apresenta e tampouco se configura como tarefa simples ou óbvia. A análise geomorfológica se apresenta, muitas vezes, subjetivamente, ou seja, a aplicação das teorias e métodos de análise no estudo da paisagem possibilitam vários enfoques, ora mais sensíveis à interpretação de determinados elementos, ora a outros, os quais, em conjunto, conformam uma totalidade, que é indispensável para a formação de uma identidade a qual o pesquisador experiencia determinada realidade. Descrevendo particulares condições e estruturações de relevo, comuns a respectivas realidades de seus precursores, essas propostas de análise materializam, não somente singulares perspectivas na aproximação de específicos recortes analíticos, mas e inclusive, em particulares assimilações, apropriações e correlações entre os conceitos da Tríade Geomorfológica. Os variados níveis de importância que o pesquisador dispensa aos distintos signos pertencentes e estruturadores de uma paisagem se traduzem, inevitavelmente, no método analítico por ele escolhido e sua percepção e compreensão a respeito de como esses signos se combinam e se relacionam são materializados, em última análise, pelos meios gráficos utilizados, bem como o modo como essas informações são disponibilizadas e apresentadas ao leitor (Figura 7).

\section{Figura 7 - Culminância do itinerário investigativo em Geomorfologia e suas plurais produções e sistematizações}

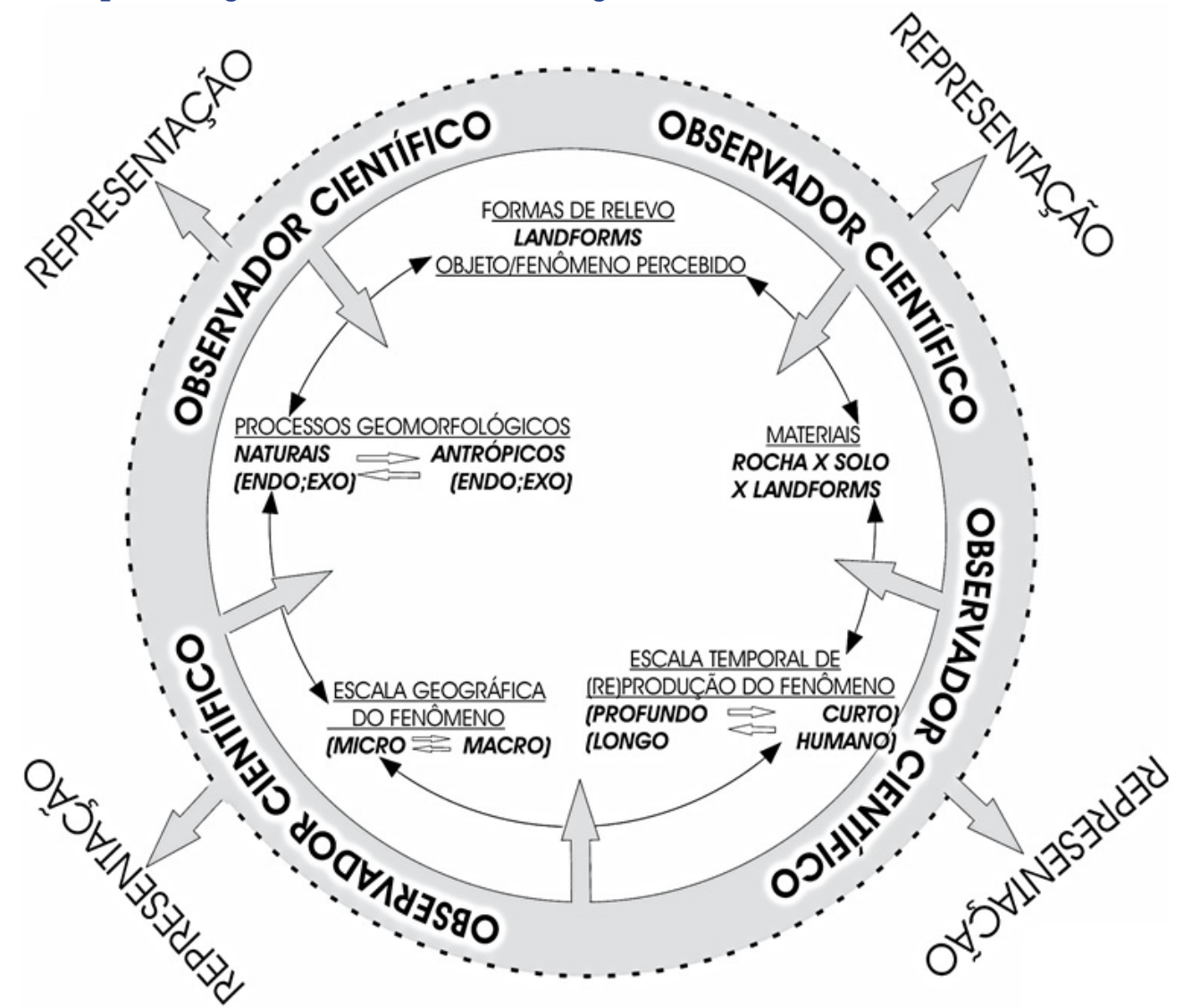


Assim, em consequência da combinação entre a necessidade de se conhecer, nomear e organizar o ambiente, a compreensão do relevo e a dinâmica inerente a suas formas associadas acabam por materializar objetivos e intentos particulares, os quais valorizam, quando da apreciação direta do espaço vivido e percebido, específicos produtos geomorfológicos em face aos demais, isto é, cada sistematização assume e enfatiza, com díspares preponderâncias causais (Schumm; Lichty, 1965; Phillips, 1986, 1988), a estruturação do relevo e o modo como o geomorfólogo concebe e percebe o mundo. Em outras palavras, um caráter único e original emerge, em consequência, dessa relação indivíduo - paisagem, já que como sinaliza Paulet (2002), um inevitável sistema de filtros se interpõe entre o indivíduo e o objeto observado (Figura 8).

\section{Figura 8 - Possíveis filtros que alvorecem entre o observador e a paisagem O SISTEMA DE FILTROS}

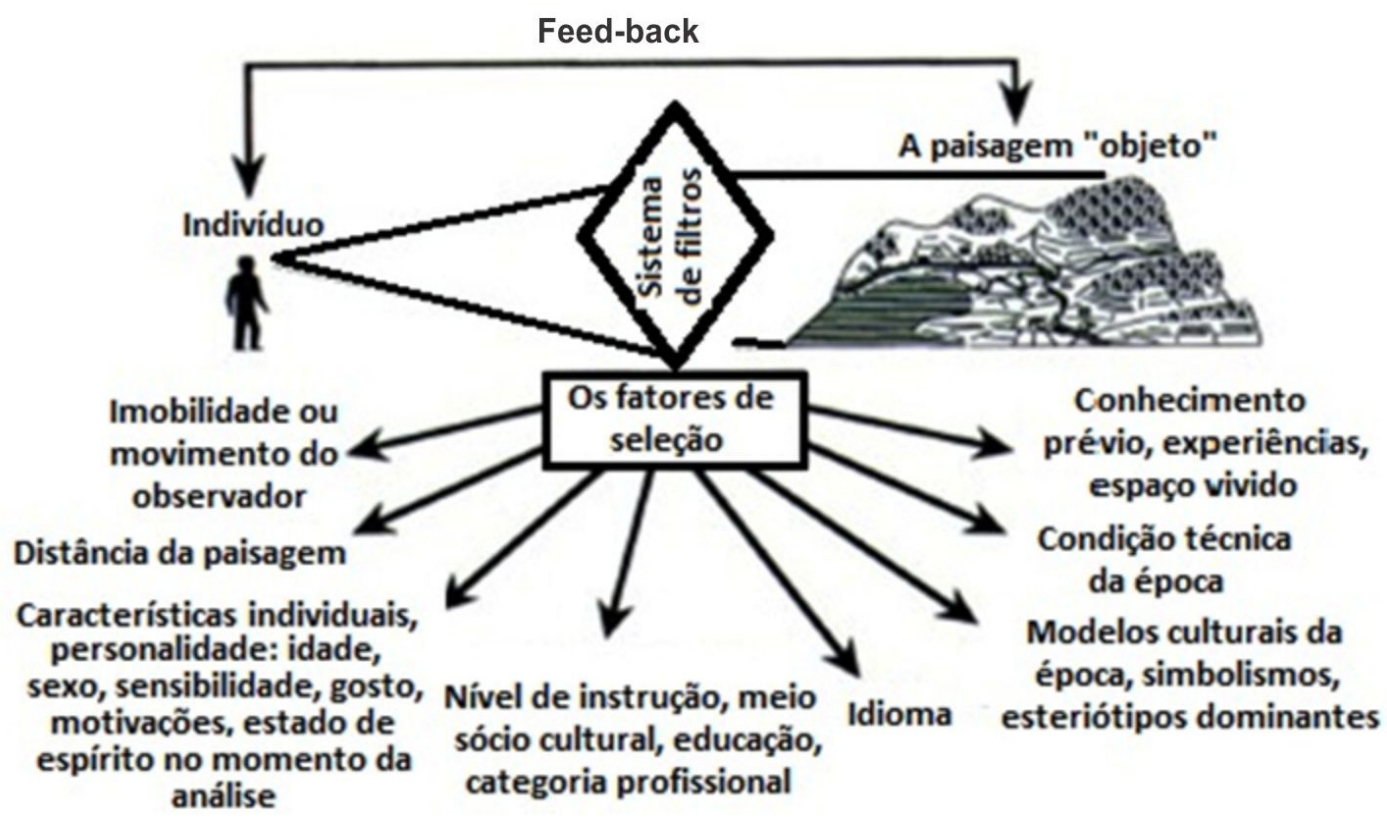

fonte: Adaptado de Paulet (2002).

A paisagem nunca é, portanto, uma representação homogênea e igualitária para os observadores, já que entre o observável e o interpretativo, pressupõem-se alvoreceres infindáveis de sentidos, fatores e sensações que identificam, selecionam, associam, ordenam e qualificam, em distintos modos, os diferentes signos da paisagem (Partoune, 2004). Um caráter único e original emerge, em consequência, dessa relação indivíduo - paisagem. Baseada e centrada no bojo de valores idiossincráticos e na própria relação pessoal com que o observador experiencia o mundo, aqueles conceitos fundantes da Geomorfologia ganham contornos e correlações próprios, gerando novas interpretações e percepções da realidade, trasladados e moldados a partir da sensibilidade que cada um traz consigo (material de fundo ou intelectual). Essas e outras experimentações vivenciadas no desenvolver da vida do indivíduo, constituem um véu translúcido, o qual é transposto quando da leitura e análise de um objeto, de uma realidade. Parafraseando Kant (1980), tudo aquilo que chega à consciência é profundo e completamente ajustado, simplificado, esquematizado e (re)interpretado. 
À vista do exposto, as diversas pesquisas geomorfológicas e suas transfigurações ao longo do tempo, despontam-se como produtos de plurais sistemas de ideias que suportam, muitas vezes, (in)conscientemente essas investigações. As principais teorias e modelos de evolução do relevo terrestre propostas ao longo do último século representam claramente as rupturas epistemológicas pelas quais o pensamento geomorfológico passou e experimentou, atreladas uniformemente às diferenças de percepção e valorização de respectivos signos que compõem o ambiente. Mudanças na perspectiva do olhar sobre a paisagem, oriundas do alvorecer de novos conceitos, ideias, métodos, técnicas e pressupostos, culminam, muitas vezes, invariavelmente, em percepções distintas, às vezes opostas, de uma mesma realidade, um mesmo objeto.

\section{Considerações finais}

Satisfatórias explicações científicas sobre o mundo não estão estruturadas sob a égide de uma só teoria geral (Rhoads; Thorn, 1993). Pelo contrário. A prática mais comumente experienciada e extensivamente identificada nas ciências é o caráter evolutivo do conhecimento científico (Kuhn, 1978), no sentido de ele abraçar uma sequência de acontecimentos, por vezes ordenados, através da sua história que, quando convergidos no presente, permitem identificar os reais objetivos que movem seu desenvolvimento e balizam suas ações, a partir do reconhecimento de seus respectivos conceitos fundantes.

Erigida nos contrafortes da ciência moderna e em seu caráter fundamentalmente de síntese, a Geomorfologia amalgamou numerosos conhecimentos que se encontravam francamente dispersos. Estruturando-se doravante sobre dois eixos norteadores majoritários, com abordagens teórico-metodológicas distintas mas com objetivos convergentes, tanto os pertencentes à perspectiva histórica de Davis (1899) quanto os orientados pela linha naturalista-processual germânica empreenderam esforços na tentativa de entender os ambientes e as paisagens atuais, não prescindindo para isso de uma análise das transformações ambientais pretéritas.

A simplicidade e aplicabilidade das propostas que daí alvoreceram, baseadas em precisos e limitados conceitos, mantiveram-se tradicionalmente como linhas mestras na natural evolução do campo científico (Kuhn, 1978), ao dar oportunidade a um estilo lúcido, convincente e conciliatório, pertinentes chaves interpretativas para se decifrarem os últimos estágios da história terrestre.

Ainda que porventura mais teórica em sua proposição inaugural (Davis, 1899), valorizam-se sobremaneira, com efeito, o empírico e a observação de campo na prática geomorfológica (Rhoads; Thorn, 1996). A confiabilidade e a credibilidade do conhecimento científico em Geomorfologia assentam-se no fato de que as proposições de observação que formam a base de seu conhecimento são seguras e confiáveis, porque os fatos podem ser averiguados/falsificados (Popper, 1982) pelo uso direto dos sentidos. Daí, a fidedignidade de suas proposições será transmitida às leis e teorias delas derivadas, desde que as condições lógicas para a generalização sejam legítimas e estejam satisfeitas (Jolivet, 1969; Moss, 1977).

Justamente pelo fato de o corpo do conhecimento em Geomorfologia ser construído a partir da base fornecida pelos sentidos e por permitir, consequentemente, diversos e plurais recortes escalares de aproximação, tanto temporais quanto espaciais, os geomorfólogos constroem e (re)modelam continuamente suas ideias e metodologias, a fim de melhor acomodar 
mudanças, em qualidade ou quantidade, das informações obtidas sobre as diferentes paisagens que se estruturam entre essas diversas escalas. Pelo fato de muitos conceitos terem sido (re) construídos e modificados ao longo da trajetória da edificação da Geomorfologia, ampliaram-se largamente a linguagem conceitual e o próprio horizonte pesquisável, favorecendo, em última análise, o alvorecer de inúmeras possibilidades de interpretação, classificação e correlação entre os conceitos fundantes da Tríade Geomorfológica. Logo, quando os geocientistas, ao se debruçarem sobre esses pressupostos fundantes da Geomorfologia à luz de diferentes perspectivas idiossincráticas e teóricas, essas emanam, amiúde, interpretações e abordagens diversas que deságuam não só na natureza de inferências causais, mas sobretudo no apego a certos princípios, conceitos, que ditam e regulam quais são os verdadeiros fatos e informações, bem como sua quantidade e qualidade quando da estruturação de uma conclusão cientificamente válida. Nesse contexto, quando vistos posteriormente, os mesmos fatos morfológicos outrora observados na paisagem em ressonância do despontar de novos preceitos, ideais, técnicas e pressupostos podem revelar-se sob novos contornos teóricos (i.e. Davis, 1899; King, 1956). Consequentemente, as plurais propostas de abordagem da paisagem geomorfológica materializam nada mais do que distintas perspectivas de análise e arranjo causal sobre aqueles habituais e largamente conhecidos conceitos fundantes da ciência geomorfológica. Em última análise, essas proposições modelares de representação cristalizam e traduzem invariavelmente as percepções e assimilações de como os geocientistas interferem, percebem e atuam no e ao longo do mundo.

\section{Referências}

AB' SABER, A. N. Um conceito de geomorfologia a serviço das pesquisas sobre o Quaternário. Geomorfologia, São Paulo, v. 18, p. 1-23, 1969.

ABREU, A. A. A teoria geomorfológica e sua edificação: análise crítica. Revista Brasileira de Geomorfologia, São Paulo, v. 4, n. 2, p. 51-67, 2003.

Análise geomorfológica: reflexão e aplicação uma contribuição ao conhecimento das formas de relevo no Planalto de Diamantina. Tese (Livre-Docência em Geografia) - Faculdade de Filosofia, Letras e Ciências Humanas, Universidade de São Paulo, São Paulo, 1982.

BARROS, P. H. C. A.; VALADÃO, R. C. Cronologia na corologia: a construção de uma perspectiva temporal. Revista da Universidade Federal de Minas Gerais, v. 23, n. 1-2, p. 196-221, 2016.

BIROT, P. Les méthodes de la morphologie. Paris: Presses Universitaires de France, 1955.

BRYAN, K. Physiography. Geological Society of America, 50th Anniversary Volume, p. 3-15, 1941.

BÜDEL, J. Climatic geomorphology. Princeton: Princeton University Press, 1982.

CAILLEUX, A.; TRICART, J. Le problème de la classification des faits géomorphologiques. Annales de Géographie, v. 65, n. 349, p. 162-186, 1956. 
CAMPY, M.; MACAIRE, J. J. Géologie des formations superficielles: géodynamique, faciès, utilisation. Paris: Marron, 1989.

CHALMERS, A. O que é a ciência afinal? São Paulo: Brasiliense, 1993.

CHAMBERLIN, T. C. Studies for students: the method of multiple working hypotheses. The Journal of Geology, v. 5, n. 8, p. 837-848, 1987.

CHORLEY, R. J. Bases for theory in Geomorphology. In: EMBLETON, C.; BRUNSDEN, D.; JONES, D. K. C. Geomorphology: present problems and future prospects. Oxford: Oxford University Press, 1978. Geomorphology and general system theory. US Geological Survey Professional Paper 500 B, p. 1-10, 1962

; BECKINSALE, R. P.; DUNN, A. J. The history of the study of landforms.

London: Methuen, 1973. v. II: The life and work of William Morris Davis.

CHRISTOFOlETTI, A. Geomorfologia. 2a. ed. São Paulo: Edgard Blücher, 1980.

COLTRINARI, L. Geomorfologia: caminhos e perspectivas. Revista Brasileira de Geomorfologia, v. 1, n. 1, p. 44-47, 2000.

COTTON, C. A. Alternating Pleistocene morphogenetic systems. Geology Magazine, p. 95, p. 125-136, 1958.

CRICKMAY, C. H. A preliminary inquiry into the formulation and applicability of the geological principle of uniformity. Calgary, CA: Evelyn de Mille, 1959.

DAVIS, W. M. The geographical cycle. Geographical Journal of the Royal Geographical Society, v. 14, p. 481-504, 1899.

DOTT, R. H. JR. 1982 SEPM Presidential Address: Episodic Sedimentation--How Normal Is Average? How Rare Is Rare? Does It Matter? Journal of Sedimentary Research, v. 53, n. 1, p. 5-23, 1983.

GILBERT, G. K. Land sculpture in the Henry Mountains. In: US Geography and Geology Survey of the Rocky Mountain Region. Washington, DC: General Printing Office, 1887.

GREGORY, K. J. A natureza física. Rio de Janeiro: Bertrand Brasil, 1992.

HACK, J. T. Interpretation of erosional topography in humid/temperate regions. American Journal of Science (Bradley volume), v. 258-A, p. 80-97, 1960.

HAMELIN, L. E. Géomorphologie: Géographie globale-géographie totale. Cahiers de Géographie de Québec, v. 8, n. 16, p. 199-218, 1964.

HARRISON, S. On reductionism and emergence in geomorphology. Transactions of the Institute of British Geographers, v. 26, n. 3, p. 327-339, 2001.

HETTNER, A. Die Geographie: Ihre Geschichte, ihr Wesen und ihre Methoden. Breslau, PL: Ferdnand Hirt, 1927. 
Die Oberflaechenformen des Festlandes. Leipzig, DE: B. G. Teubner, 1921.

HORTON, R. E. Erosional development of streams and their drainage basins: hydrophysical approach to quantitative morphology. Bulletin Geological Society of America, v. 56, p. 275-370, 1945.

HUME, D. Investigação acerca do entendimento humano. São Paulo: Nova Cultural, 1989. (Coleção Os Pensadores.)

JOLIVET, R. Tratado de filosofia. Rio de Janeiro: Agir, 1969.

KANT, I. Crítica da razão pura. São Paulo: Abril Cultural, 1980. (Coleção Os Pensadores.)

KING, L. C. The morphology of the Earth: A study and synthesis of world scenery. Edinburgh/London: Oliver \& Boyd, 1967.

A geomorfologia do Brasil oriental. Revista Brasileira de Geografia, v. 18, n. 2, p. 147-265, 1956.

Canons of landscape evolution. Bulletin of the Geology Society of America, Washington DC, v. 64, n. 7, p. 721-732, 1953.

KLEIN, C. La notion de rythme en morphologie. Norois, v. 7, p. 373-387, 1960.

KLIMASZEWSKI, M. Problems of geomorphological mapping. Varsóvia: Academia Polonesa de Ciências, 1963. (Estudo Geográfico, 46.)

KOHLER, H. C. A escala na análise geomorfológica. Revista Brasileira de Geomorfologia, v. 2, n. 1, p. 21-23, 2001.

KÜGLER, H. Zur Aufgaben der geomorphologischen Forschung und Kartierung in der DDR.

Petermanns Geographische Mitteilungen, v. 120, n. 2, p. 154-160, 1976.

KUHN, T. A estrutura das revoluções científicas. São Paulo: Perspectiva, 1978.

LAKATOS, I. O falseamento e a metodologia dos programas de pesquisa científica. In: LAKA-

TOS, I.; MUSGRAVE, A. A crítica e o desenvolvimento do conhecimento. São Paulo: Cultrix/Edusp, 1979. p. 109-243.

LEFEBVRE, H. Lógica formal, lógica dialética. 5a. ed. Rio de Janeiro: Civilização Brasileira, 1991.

MARTONNE, E. Tratado de geografía física. Barcelona: Juventud, 1964.

MENEGAT, R.; FERNANDES, L. A. D. O método da investigação científica na geologia: uma abordagem através do exemplo heurístico da caixa-preta. Revista Brasileira de Geociências, v. 24, n. 3, p. 177-188, 1994.

MORAES, A. C. R. A gênese da geografia moderna. São Paulo: Hucitec/Edusp, 1989. MORISAWA, M. Tectonics and geomorphic models. In: MELHORN, W. N.; FLEMAL, R. C. Theories of landform development. London: George Allen \& Unwin, 1975. p. 199-216. MOSS, R. P. Deductive strategies in geographical generalization. Progress in Physical Geography, v. 1, n. 1, p. 23-39, 1977. 
PARTOUNE, C. La dynamique du concept de paysage. Revue Éducation Formation, n. 275, sept. 2004. Disponível em: http://www.lmg.ulg.ac.be/articles/paysage/paysage_concept.html. Acesso em: ago. 2012.

PAULET, J.-P. Les représentations mentales en géographie. Paris: Anthropos, 2002. (Collection Géographie.)

PENK, W. Morphological analysis of landforms: a contribution to physical geology. London: MacMillan, 1953. Disponível em: http://geomorphology.sese.asu.edu/Papers/ Penck.pdf. Acesso em: 21 out. 2017.

PHILLIPS, J. D. The role of spatial scale in geomorphic systems. Geographical Analysis, v. 20, p. 308-317, 1988.

Sediment storage, sediment yield and timescales in landscape denudation. Geographical Analysis, v. 18, p. 161-167, 1986.

POPPER, K. R. Conjecturas e refutações. 2a. ed. Brasilia: Universidade de Brasilia, 1982. (Coleção Pensamento Científico, 1.)

A lógica da pesquisa científica. São Paulo: Cultrix, 1975.

REYNAUD, A. Épistémologie de la géomorphologie. Paris: Masson, 1971.

RHOADS, B. L.; THORN, C. E. Observation in geomorphology. In: The Scientific Nature of Geomorphology: Proceedings of the 27th Binghamton Symposium in Geomorphology held 27-29 September 1996. Hoboken, NJ: John Wiley \& Sons, 1996. p. 21-56.

Geomorphology as science: the role of theory. Geomorphology, v. 6, n. 4, p. $287-$ 307, 1993.

RITTER, D. F. Process Geomorphology. Dubuque, IA: W.C. Brown, 1986.

ROQUE ASCENÇÃO, V. O. Os conhecimentos docentes e a abordagem do relevo e suas dinâmicas nos anos finais do Ensino Fundamental. Tese (Doutorado em Geografia) - Instituto de Geociências, Universidade Federal de Minas Gerais, Belo Horizonte, 2009.

SAADI, A. Modelos morfogenéticos e tectônica global: reflexões conciliatórias. Geonomos, v. 6, n. 2, p. 55-63, 1998.

SCHUMM, S. A.; LICHTY, R. W. Time, space, and causality in geomorphology. American Journal of Science, v. 263, p. 110-119, 1965.

SELBY, M. J. Earth's changing surface: an introduction to geomorphology. Oxford/New York: Clarendon/Oxford University Press, 1985.

SOUZA, C. J. O. Geomorfologia no Ensino Superior: difícil, mas interessante! Por quê? Uma discussão a partir dos conhecimentos e das dificuldades entre graduandos de geografia. Tese (Doutorado em Geografia) - Instituto de Geociências, Universidade Federal de Minas Gerais, Belo Horizonte, 2009. 
STRAHLER, A. N. Statistical analysis in geomorphic research. Journal of Geology, Chicago, v. 62, n. 1, p. 1-21, 1954.

Dynamic basis of geomorphology. Bulletin Geological Society of America, v. 63, n. 9, p. 923-938, 1952.

. Equilibrium theory of erosional slopes approached by frequency distribution analysis Part I. American Journal of Science, v. 248, p. 673-696, 1950a.

. Equilibrium theory of erosional slopes approached by frequency distribution analysis Part II. American Journal of Science, v. 248, p. 800-814, 1950 b.

STUART MILL, J. Sistema de lógica dedutiva e indutiva. Trad. João Marcos Coelho. São Paulo: Nova Cultural, 1989.

TRICART, J. L. F. Geomorphology for the future: geomorphology for development and development for geomorphology. In: INTERNATIONAL CONFERENCE ON GEOMORPHOLOGY, 1, 1985, Chichester, UK. Anais... Chichester, UK: University of Manchester, 1986.

TRICART, J. Principes et méthodes de la géomorphologie. Paris: Masson, 1965.

VITTE, A. C. Da ciência da morfologia à geomorfologia geográfica: uma contribuição à história do pensamento geográfico. Mercator, v. 7, p. 113-120, 2008.

WILHELMY, H. Klimageomorphologie in Stichworten. Kiel, DE: Ferdinand Hirt, 1974.

WOLMAN, M. G.; MILLER, J. P. Magnitude and frequency of forces in geomorphic processes. The Journal of Geology, v. 68, n. 1, p. 54-74, 1960.

WOOLDRIDGE, S. W. The trend of geomorphology. Transactions and Paper, Institute of British Geographers, v. 25, p. 29-35, 1958. 